\title{
Movement Restricting Heterotopic Ossification After Free Functioning Gracilis Muscle Transfer to the Elbow: A Case Report
}

\author{
Sanjog Sharma ${ }^{1}$, Vybhav Deraje ${ }^{2 *}$ and Rajendra S Gujjalanavar ${ }^{3}$ \\ ${ }^{1}$ Associate Consultant, Department of Plastic and Reconstructive Surgery, Sakra \\ World Hospital, Bangalore, India \\ ${ }^{2}$ Consultant, Department of Plastic and Reconstructive Surgery, Sakra World \\ Hospital, Bangalore, India \\ ${ }^{3}$ Senior Consultant and Head, Department of Plastic and Reconstructive Surgery, \\ Sakra World Hospital, Bangalore, India \\ *Corresponding Author: Vybhav Deraje, Consultant, Department of Plastic and \\ Reconstructive Surgery, Sakra World Hospital, Bangalore, India.
}

\begin{abstract}
We report a case of development of a movement restricting heterotopic ossification after a free functioning gracilis muscle transfer performed for elbow flexion in a patient with pan brachial plexus palsy. We also present the management of the case including the repair of the brachial artery which was thinned out by the lesion. To the best of our knowledge, this is the first case in literature which reports heterotopic ossification after a free functioning muscle transfer.
\end{abstract}

Keywords: Heterotopic Ossification; Free Functioning Muscle Transfer; Brachial Plexus Injury

\section{Introduction}

Heterotopic or Ectopic ossification is the formation of lamellar bone in soft tissues or other tissues remote from the usual location of bone. Formation of heterotopic ossification (HO) following tissue transfer for reconstruction has been reported anecdotally [1-5]. One of these studies also reported that the severity of heterotopic ossification is significantly higher in muscle flaps around the joints [5]. We present a case of a large, movement restricting, heterotopic calcification which developed after a free functioning gracilis muscle transfer was carried out for elbow flexion in a patient with pan brachial plexus palsy (where all the nerves and levels of brachial plexus were damaged). To the best of our knowledge, this is the first report of heterotopic ossification after a free functioning muscle transfer (FFMT).
Received: December 23, 2020

Published: January 28, 2021

(C) All rights are reserved by Vybhav Deraje.,

et al. 
contralateral C7 transfer to the axillary, musculo-cutaneous and median nerve (Nerve grafts from contralateral C7 spinal nerve to axillary nerve, musculocutaneous nerve and median nerve). Partial recovery of shoulder abduction was achieved but he failed to get any active movement in the elbow and wrist. A decision was made to proceed with free functioning gracilis muscle transfer for elbow flexion and a wrist arthrodesis after completion of 2 years of physiotherapy post $\mathrm{C} 7$ transfer procedure. At that point of time, he had complete range of passive movements at the elbow. Nine months after the FFMT surgery, he presented with unsatisfactory improvement in active range of movements, mass in the right elbow and restriction of even passive range of movements.

CT scan (Figure 1) demonstrated a large ( $5 \mathrm{~cm}$ diameter) heterotopic calcification around the insertion of the biceps and brachialis tendon. The right elbow was explored under general anaesthesia and heterotopic ossification mass was excised (Figure 2). During surgery, it was noted that the brachial artery was thinned out and subsequently also ruptured during the complete excision of the mass. Vascular continuity was reestablished using ipsilateral cephalic vein graft which was found locally. Patient resumed graded physiotherapy after a post-surgical break of 3 weeks and his passive range of movements have improved (Figure 3). We are awaiting improvement in active range of movements.

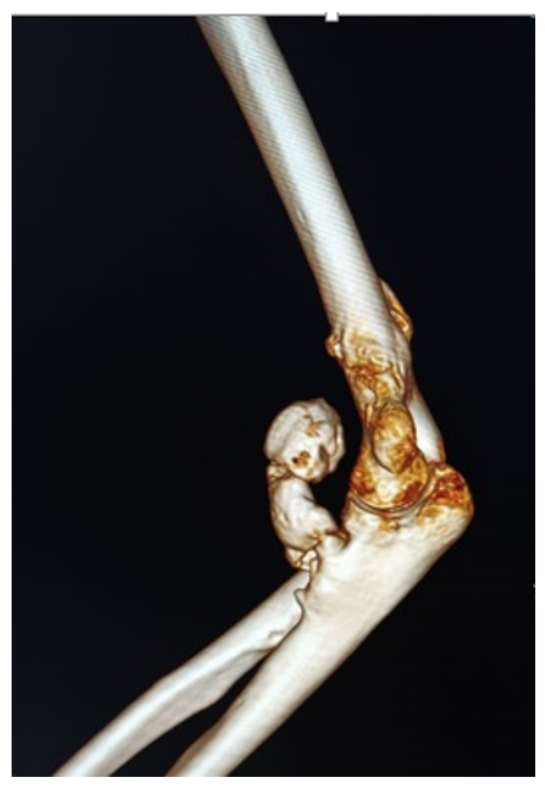

Figure 1: CT scan showing large $5 \mathrm{~cm}$ diameter bony mass at the elbow around the region of biceps and brachialis tendon.

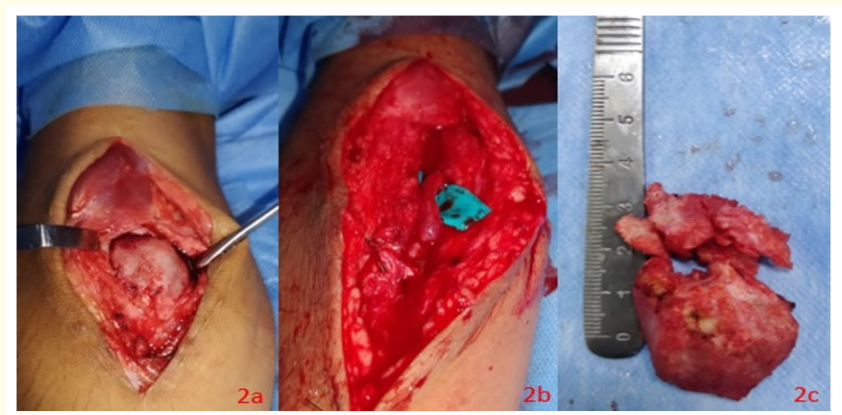

Figure 2: Intra-operative image (2a), Brachial artery repair using Cephalic vein graft (2b), Excised specimen (2c).
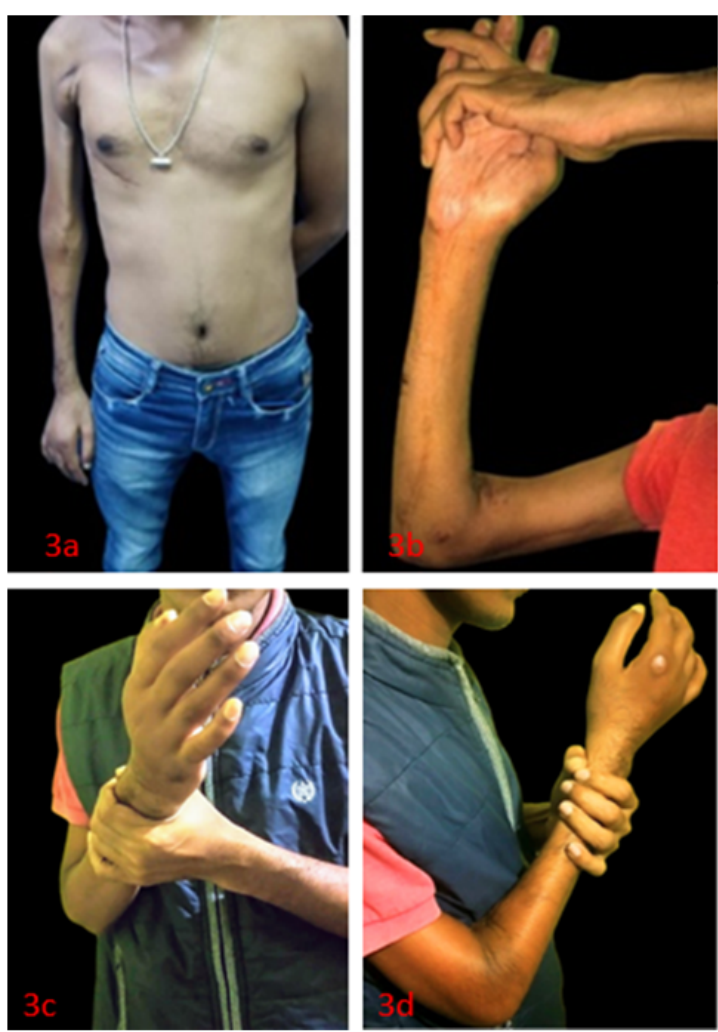

Figure 3: Pre-operative (3a) and post-operative (3b, 3c, 3d) pictures of extent of passive range of movement (flexion) at the elbow. 


\section{Discussion}

The development of ectopic ossification in soft tissues after injury, burns, surgery and neurological injury is a well known complication and several authors have attempted to explain the exact etiology, most prominently by McCarthy and Sundaram [6]. The underlying pathology is generally attributed to the osteogenic potential of periosteum which gets implanted onto the soft tissue and giving rise to the ossification. In our case, the gracilis muscle was sutured to the biceps tendon in the primary operation and it didn't involve periosteal manipulation. A hematoma around the surgical site and eventual development of $\mathrm{HO}$ could have been the possible trigger in our case. A review by Meyers., et al. also supports this theory that HO starts separately and then may fuse with the periosteum secondarily [7].

With little donor site morbidity, gracilis free functional muscle transfer is commonly employed in brachial plexus injury where the native muscles have undergone irreversible damage. Literature search revealed reports of heterotopic ossification following free fibula flap mainly along the vascular pedicle and also rarely distant to the site of the vascular pedicle $[8,9]$. Non-free fibula flap with reported heterotopic calcification includes radial forearm flap [10], supraclavicular island flap [11] and temporal fascial flap [12]. We believe that our report is the first case report of HO developing after a free functioning gracilis muscle transfer surgery in a brachial plexus patient.

Our patient had full range of passive movements before FFMT surgery. But we acknowledge that we don't have radiographic proof of absence of $\mathrm{HO}$ prior to surgery in the background of the old humerus fracture. There is a genuine possibility that the HO process could have been brewing and the FFMT surgery merely hastened the process and made it more severe. This is one of the limitations of our report.

The ideal timing of excisional surgery for HO has been suggested in the literature as $12-18$ months post the injury/event [13], to facilitate complete maturation of bone before excision. But in our case, since the patient was in an active physiotherapy protocol for recovery from brachial plexus surgery, it was felt prudent to proceed at an earlier time ( 9 months post FFMT surgery).

As mentioned in the review by Meyers., et al. [7], HO doesn't respect anatomic borders and frequently encases neurovascular structures which may lead to inadvertent injury during excision as was noted in our case where the brachial artery was ruptured. This needed immediate repair using Cephalic vein which was readily available in the operative site to maintain vascularity to the upper limb.

In other similar reports, the HO didn't cause serious functional issues. Our case is also unique by the fact that it caused movement restriction at the elbow joint. Surgeons adopting FFMT for brachial plexus injuries need to consider this complication if their patients are not progressing satisfactorily during physiotherapy.

\section{Conclusion}

Although not reported previously, heterotrophic calcification can occur after a free functioning muscle transfer and this needs to be considered in a patient who is not progressing satisfactorily during the physiotherapy phase or has worsening of range of movements. Early surgical excision of the restricting mass is crucial for physiotherapy to resume at the earliest.

\section{Acknowledgements}

The authors wish to thank Mr Abdul Majeed (Physician assistant - Dept of Plastic and Reconstructive surgery) and Ms Senthamarai Selvi (Plastic surgery nurse) for their help in data collection and documentation.

\section{Conflict of Interest}

None.

\section{Bibliography}

1. Adler N and Yaffe B. "Ectopic bone formation following temporalis muscle transposition for facial paralysis: A rare complication?" Annals of Plastic Surgery 55 (2005): 442.

2. Bakker XR and Nicolai JP. "Ectopic bone formation after temporal muscle transposition for facial paralysis". Plastic and Reconstructive Surgery 105 (2000): 2079-2081.

3. Rubayi S., et al. "Heterotopic ossification as a complication of the staged total thigh muscles flap in spinal cord injury patients". Annals of Plastic Surgery 29.1 (1992): 41-46.

4. McInnes CW., et al. "Management of pelvic heterotopic ossification post-myocutaneous flap reconstruction of a sacral pressure ulcer". Canadian Journal of Plastic Surgery 19.2 (2011): $60-61$. 
5. Wheatley BM., et al. "Heterotopic Ossification following Tissue Transfer for Combat-Casualty Complex Periarticular Injuries". Plastic and Reconstructive Surgery 136 (2015): 808e-814e.

6. McCarthy EF and Sundaram M. "Heterotopic ossification: A review”. Skeletal Radiology 34 (2005): 609-619.

7. Meyers C., et al. "Heterotopic Ossification: A Comprehensive Review". JBMR Plus 3.4 (2019): e10172.

8. Mays AC., et al. "Rare presentation of heterotopic ossification along a fibula free flap pedicle in a high-volume microvascular reconstruction practice". Head and Neck 40.3 (2018): E21-E24.

9. Panaretou E., et al. "Heterotopic ossification in the submental triangle remote from the vascular pedicle after reconstruction with a fibular free flap: a previously unreported complication". British Journal of Oral and Maxillofacial Surgery 54.4 (2016): 460-462.

10. Gangidi SR and Courtney D. "You reap what you sow"- A case of heterotopic ossification within a fasciocutaneous radial forearm free flap reconstruction". International Journal of Oral and Maxillofacial Surgery 42.4 (2013): 458-459.

11. Bertroche JT., et al. "Prominent Cervical Heterotopic Calcification Following Supraclavicular Island Flap Reconstruction". Ear Nose and Throat Journal 20 (2020): 145561320943346.

12. Price GJ and Stewart KJ. "Heterotopic ossification of a temporal fascial flap pedicle in ear reconstruction". Journal of Plastic, Reconstructive and Aesthetic Surgery 63.2 (2010): e146-e147.

13. McAuliffe JA and Wolfson AH. "Early Excision of Heterotopic Ossification about the Elbow followed by Radiation Therapy". Journal of Bone and Joint Surgery 79.5 (1997): 749-755.

\section{Assets from publication with us}

- Prompt Acknowledgement after receiving the article

- Thorough Double blinded peer review

- Rapid Publication

- Issue of Publication Certificate

- High visibility of your Published work

Website: www.actascientific.com/

Submit Article: www.actascientific.com/submission.php

Email us: editor@actascientific.com

Contact us: +919182824667 